\title{
On Film Polls and Pinoy Rebyu
}

Interview with Skilty C. Labastilla

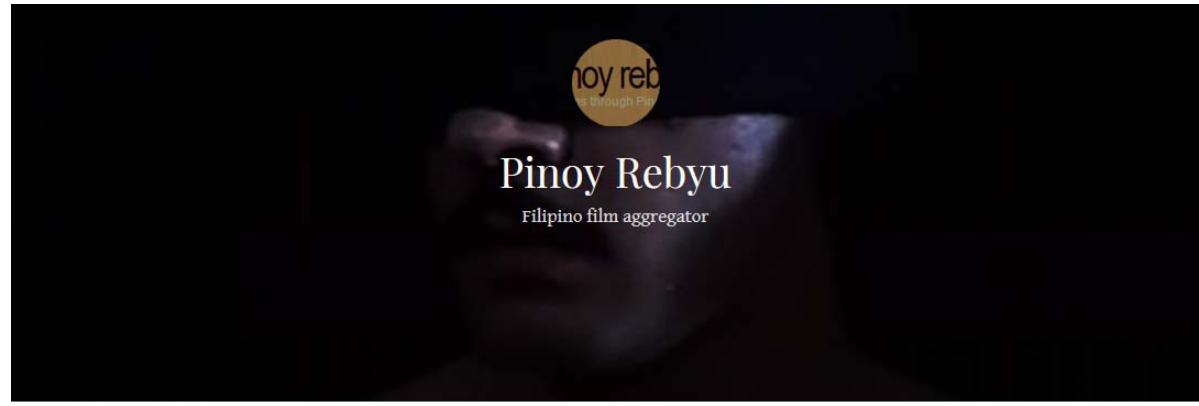

Patrick F. Campos (PFC): What is your motivation or rationale for coming up with a listing of great or best Filipino films?

Skilty C. Labastilla (SCL): When I started Pinoy Rebyu in 2010 with a couple of friends, our goal was to come up with a local equivalent of Metacritic or Rotten Tomatoes, where film reviews are collated and scored to come up with an average score per film. In 2011, we started our Yearend Poll feature by inviting 19 film reviewers to submit their top 10 films and performances of the year.

I've always been fond of "Best of" lists, but most of the "Best Films of All Time" lists I've read up to that point were lists by foreign critics and filmmakers. I knew of course that Joel David had already come up with a 1989 poll of greatest Pinoy films (published in the same year) and that Noel Vera came up with his own list of 100 best local films in 2007. In 2012, Sight $\&$ Sound, which polls critics and filmmakers every 10 years, released its "Best Films of All Time" list, where Vertigo (Hitchcock, 1958) dislodged Citizen Kane (Welles, 1941), which has been topping the poll since 1962, as the best all-time movie. In 2013, we thought it would be fun to compare the choices of current film reviewers and filmmakers to the choices of those polled in 1989 in order to see which local films have stood the test of time and which ones have fallen out of favor, as well as which one are now deemed the new classics. The poll on the best Filipino films of the 21st century was also inspired by a couple of listings conducted internationally, notably by the $B B C$ in August 2016 and the New York Times in June 2017.

We were cognizant of the fact that no poll of "Best Whatever" can ever be objective. So much of the result depends on whom we invite as respondents and who eventually responds to the invitation. For 
our yearend polls, it was relatively easier to keep track of the active film reviewers. We had to have evidence that a reviewer has seen and reviewed majority of the significant film outputs of the year for them to be invited to take part in the poll. However, for the two major polls we conducted, the "Greatest Pinoy Films of All Time" and the "Best Pinoy Films of the 21st Century," we understood that we would just have to take a leap of faith and assume that our invited respondents for the first poll have seen most of the significant Filipino films ever produced or, for the second poll, have at last seen the important films of the twentyfirst century.

PFC: What processes did you go through in coming up with the lists? And what have you learned from these processes? Have you encountered problems or criticisms?

SCL: For the best-of-all-time poll, we sent out invitations to filmmakers (directors, producers, and screenwriters), film critics, reviewers, academics, and archivists. All in all we sent out more than 200 invitations via Facebook Messenger and waited for about two months for their response, with lots of follow-up messages within those months. Eventually, we received 81 responses. We figured that most of those who did not respond after two or three follow-up messages either did not want to be bothered or did not have time to come up with a list. Joel David was the only one kind enough to tell us why he could not participate, saying he would like to move on from canonizing projects since he did not want to repeat himself.

For the best-of-the-21st-century poll, we thought that inviting filmmakers as respondents would be tricky because the local filmmaking community is not that big and choosing the films of some friends over those of other friends might lead to unnecessary tension. So we basically copped out and narrowed down our invitees to around 50 critics, reviewers, academics, and archivists, though some of them were also active filmmakers. At present, because of the structure of film screenings and distribution in the country where majority of the film festivals are held only in Metro Manila, almost all film critics and reviewers are based in the capital. We were lucky to have been able to invite two academics from the Visayas, Paul Grant and Misha Anissimov, and one young critic from Mindanao, Jay Rosas, who, despite the geographic challenges, were all fortunate enough to see many of the significant films and thus were able to submit ballots to the poll. As much as we wanted to have a geographically balanced set of voters and avoid a Manila-centric result, we were constrained by this very real problem of not having enough 
people from the regions who had access to many Filipino films in the first place. We eventually received 33 ballots. Like in the best-of-alltime poll, there was one individual in this second poll who expressed his regrets and said that he did not like the possibility of alienating his friends in case they find out that their films were not on his list. In addition, he conveyed a concern that such a poll might favor the more well-known films over the obscure ones, especially if the invited voters had only seen the more popular and lauded films. That was a very valid issue, and we assured him that we were extra careful in inviting voters precisely because we did not want to skew the poll against less popular films. We scored films by giving a score of 10 to the first-ranked film, nine to the second-ranked film, and so on. There were several voters, though, who submitted unranked films, so we gave each film in their top 10 list a score of 5.5 (the median of 1 and 10), with the assumption that the reason why they did not rank their choices was because they gave equal weight to all of them.

When we tallied the results for the "Greatest Pinoy Films of All Time," one minor problem that we faced was the great number of ties in the 50th to 100th places. We thought too many ties would look clunky in the blog post, so we solved this by limiting the list just to the top 50 . It would only be several years later that we would finally figure out a neat three-step way to break ties, so that's when we appended a longer list that included films in the 50th to 100th places to our original posts. To break ties, we first considered the number of times the tied films were mentioned by voters. For instance, if two films both scored 48 points, the film that was mentioned more times got the higher rank. If the films were mentioned the same number of times, we moved to the second step, which was to see which film received the highest rank from voters. For example, Pagdating sa Dulo (Bernal, 1971) and One More Chance (Garcia-Molina, 2007) both received six points and was each mentioned by two voters. So we then looked at how they were ranked by these voters. Pagdating sa Dulo was ranked eighth in both ballots that mentioned it while One More Chance was ranked seventh and ninth in the two ballots that mentioned it. Thus, One More Chance was ultimately ranked higher in the final tally since it received a higher rank (seventh) than Pagdating sa Dulo. This sounds too confusing because it is, and I guess it illustrates the efforts we exerted in ensuring that a semblance of science had been incorporated in an otherwise highly subjective undertaking.

This is further illustrated in our last tie-breaking step, where we had to break a tie between or among films that have the same score, 
number of mentions, and rank. For this, the Pinoy Rebyu team-my two colleagues and I-essentially became the tie-breaking committee, and the tied film that at least two of us liked more was eventually ranked higher. Thankfully, this happened only twice. One was in breaking the tie between three films vying for 94th place: Sanda Wong (De Leon, 1955), Ina Ka ng Anak Mo (Brocka, 1979), and Dahas (Roño, 1995). The two of us who saw Sanda Wong deemed it the best of the three, so it was ranked 94. All of us saw Ina Ka ng Anak Mo and Dahas and thought the former was more superior, so the former was ranked 95 and the latter, 96. The second instance was in breaking the tie for 97th place between Nagalit ang Buwan sa Haba ng Gabi (Zialcita, 1983) and Pila Balde (Jeturian, 1999). Two of us voted for the former to be ranked higher, so Pila Balde eventually became \#98.

When we did the "Best Pinoy Films of the 21st Century" poll, ranking for the final tally was much easier since we had already established a system for breaking ties. ${ }^{1}$ We also came up with a new blog layout, which included a large film still for each ranked film and a brief commentary of a poll voter or a snippet from a published review to justify why the film deserved to be in the list.

We did not really encounter any big problems in the process of doing the two polls. I guess because we were used to the process, having done our annual poll since 2011, that we were able anticipate potential difficulties, which mainly had to do with following up those who were supposed to submit a ballot.

For the best-of-all-time poll, we were not aware of any criticisms. There could have been some minor grudges held by those who thought they should have been invited to vote in the polls, or comments about the relatively small sample size. I'm sure there were comments from those who scoff at any kind of list-making in general. But we did not come across these kinds of sentiments online. What could approximate criticism would probably be the comments about why a certain film was not on the list or why a film they did not like was on the list. But that's pretty normal for any kind of list. There will always be people who will disagree with the results.

The best-of-the-21st-century list received online criticisms, though, from several individuals-even from the voters! - mainly because of the timing of its release. The main point raised was "Why the rush when we're only 17 years into the new century?" Some questioned the title of the post ("The 50 Best Filipino Films of the 21st Century") when we published it because it was apparently misleading, and they said that we should have added "So Far" to it. We anticipated that reaction, but we 
thought the titling was self-evident: of course the list could only cover what has SO FAR been released in the 21st century since the century was obviously not over! Also, our thought process then was essentially "We want to do the list now, and no one can stop us!"

\section{PFC: What is your assessment of both the process and the product of your list-making?}

SCL: I guess my previous answer would serve as my assessment of the process. As to the product, even while we were still tabulating the bestof-all-time votes, it was clear early on that Maynila sa Kuko ng Liwanang (Brocka, 1975) and Himala (Bernal, 1982) would be the top two films because almost all ballots mentioned either or both of them. What was exciting was not only were these two films way ahead in points of the third-ranked film, Kisapmata (De Leon, 1981), but also that they were separated by a mere two points! Had there been one more person who submitted a ballot that listed Himala three places higher than Maynila, Himala would have been the top-ranked film in the list. That just goes to show that poll results are very much dependent on the subjective taste of the voters, which to us is as important as or even more exciting than the full tally. That is why we always publish the individual ballots for readers to see for themselves how people they respect voted (and for them to ignore the individual lists of people they can't stand!).

When we compared the 2013 poll results to Joel David's 1989 poll, which we recomputed using our own system, we were surprised at how little the top 10 has changed: eight of the films in the 1989 list were still in the 2013 list. Only Anak Dalita (Avellana, 1956) and Nunal sa Tubig (Bernal, 1976) dropped out of the top 10 (from 3 to 17, and from 9 to 15 , respectively) and, even then, did not drop that significantly. In 1989, Himala was \#8 with 50 points, quite far from Maynila's 112 points, and this illustrates how time has been kind to Bernal's film, which has grown in stature over the years. As for other notes in comparing the two polls, this is what we wrote on our blog then:

\section{(Quick Thoughts)}

Twenty-two films in the 1989 list have been replaced in the 2013 poll, with Brocka's Jaguar (1989) showing the most notable drop (from \#10 in 1989) to getting only one vote out of 81 in the 2013 poll. Other films notably absent in the 2013 poll are Noli Me Tangere (De Leon, 1961), previously at \#15, Salome (Guillen, 1981), previously at \#16, and de Leon's Daigdig ng mga Api (1965) and Sawa sa Lumang Simboryo (1952), both formerly \#21. 
The comparison of the two lists underscores the importance of film preservation. Daigdig ng mga Api (De Leon, 1965), for instance, has no known extant print and will unfortunately never be mentioned in future film polls. Eleven of the 22 films that bowed out of the top 50 were made before 1965, and one could argue that a good number of the 2013 voters may not have seen some of these films from the "First Golden Age."

If there were previously highly regarded films that failed to make the cut in the new poll, there are six films that have been existing when the 1989 poll was conducted but failed to garner even one vote that have aged well and found new admirers in the recent poll. These are Mababangong Bangungot (Tahimik, 1977) at \#11; Pagputi ng Uwak, Pag-itim ng Tagak (Castillo, 1978) at \#31; Bagets (Delos Reyes, 1984) at \#36; Oliver (Deocampo, 1983) at \#38; Ang Tatay Kong Nanay (Brocka, 1978) at \#40; and Salawahan (Bernal, 1979) at \#45. We'll leave you, dear readers, to tell us the possible reasons why these films are being appreciated by film experts now rather than when they came out.

I would hazard a guess and say that the reason for the high ranking of Mababangong Bangungot (Tahimik, 1977), as well as the inclusion of Oliver in the 2013 poll is that, beginning in the 1990s, more and more people realized the value of the documentary form as a tool that can equal the narrative film's power to shed a light on a particular issue or story. The mentions of Salawahan (Bernal, 1979) and Bagets (Delos Reyes, 1984) may also point to the fact that comedies have been increasingly viewed as significant cinematic outputs. In the 1989 poll, only one comedy film was mentioned: Kakabakaba Ka Ba? (De Leon, 1980 ) at \#38). But in the 2013 poll, this film rose to \#19. Salawahan and Bagets also entered the top 50, as did a recent comedic film, Ang Damgo ni Eleuteria (Zuasola, 2010) (\#50). Please see Annex for a more detailed comparison of the 1989 and 2013 polls.

For the best-of-the-21st-century poll, we anticipated that majority of the top films would be independent films, that is, those produced outside the country's main film studio system, and indeed indie films dominated the poll. Only four of the top 50 films came from the studios: Tuhog (Regal Films, Jeturian, 2000) at \#3, Booba (Viva Films, Bernal, 2001) at \#13, Dekada 70 (Star Cinema, Roño, 2002) at \#26, and Minsan May Isang Puso (Regal Films, Reyes, 2001) at \#50. The biggest uproar over the poll was the inclusion and high placement of Booba, a slapstick sex-comedy that banked heavily on its star Rufa Mae Quinto's brand of humor. Majority of the reaction was positive, with Facebook commenters tagging their friends about plans to rewatch the film soon. 
Of course, there were also those who raised their eyebrows about the film. One commenter branded the film anti-intellectual.

It wasn't surprising that many films by Lav Diaz and Brillante Mendoza, arguably the country's most lauded filmmakers today, figured in the list, and that a Diaz film would eventually get the top ranking. What was a bit surprising was that Mendoza's highest-ranked film, Serbis (2008), was only at \#6 and that two more recent films, Badil (Roño, 2013) and Ang Damgo ni Eleuteria (Zuasola, 2010), ranked higher-at \#5 and \#2, respectively. Badil was made by Chito Roño as part of the Film Development Council of the Philippines' efforts in 2013 to give veteran filmmakers a chance to make their passion films outside the studio system. Badil was seen by practically no one, but those who saw it understood that Roño made a gem of a political thriller, and its high placement in the poll augurs well for its future in terms of viewership. We knew that Ang Damgo ni Eleuteria was well-loved-for one, my Cebuano-speaking parents and siblings kept howling in laughter while watching it at the UP Film Center back in 2010-but we didn't realize it was THIS well-loved, garnering more mentions in the poll than Batang West Side (Diaz, 2001) that it landed at \#2. Damgo led a contingent of 14 regional films in the poll, and I'm sure if we do another poll like this in 10 years' time, more regional films will figure prominently in the top 50 just because we are now entering an era where the democratization of technology has allowed the voices, stories, and perspectives of artists outside Metro Manila to finally be heard and seen.

\section{PFC: What do you think has been the contribution of your canon to the public and to particular communities?}

SCL: We are happy with the public reception to both polls. Both listings have been shared thousands times on Facebook, and we can only hope that the polls have brought to the public's attention the fact that the country has a treasure trove of films waiting to be seen by the mainstream market. Many of those who shared our posts added comments like "I have only seen $12 / 50$ " or "Where can I buy these films?" That is the reason why we immediately updated the best-of-the-21st-century poll post to include details on where to access the films in the list, since increased viewership has always been our goal. The reaction of the filmmakers of the films listed has also been heartening, and many of them posted comments saying they are excited to make new films because of the confidence boost they got from being included in the lists.

\section{PFC: How do you see the activity of canon formation in the Philippines in the future?}


SCL: As exciting as list-making is to us at Pinoy Rebyu, we understand the inherent subjectivity in this kind of endeavor, for us to convince people that our polls are the final word when it comes to what is the best in Philippine cinema. We welcome similar undertakings done by other groups. The Manunuri, for example, has its lists of the best films of the 1990 s and the 2000s, and I guess in three years' time, it will release a list of the best of the 2010s. When you look at the international scene, aside from Sight $\mathcal{E}$ Sound and BBC, outfits like Indiewire, Cahiers du Cinema and many other websites regularly conduct best-films polls. In the local scene, soon after our second poll came out, CNN Philippines released its results of the best rom-com films in the last 25 years. At the end of the day, we see what we do at Pinoy Rebyu not so much as establishing THE canon but as a fun way to encourage viewership of films deemed by a small group of experts to be worth checking out.

\section{Note}

${ }^{1}$ There was one tie that we ultimately decided not to break, though, because just a couple hours after we first posted the top 50 films, we noticed that there was one ballot that was inadvertently left out of the final tally. After recomputing, we found that cast and crew of both Himpapawid and Minsan May Isang Puso had already celebrated their films' inclusion in the list. So instead of dropping one of the films to \#51, we agreed to let them stay tied at \#50. 
Annex

\section{Matrix of top 51 films in the 1989 Joel David poll and the 2013 Pinoy Rebyu poll of the best Filipino films of all time}

\begin{tabular}{|c|c|}
\hline 1989 poll & 2013 poll* \\
\hline $\begin{array}{l}1 \quad \text { Maynila sa mga Kuko ng Liwanag (Lino } \\
\text { Brocka, 1975) }\end{array}$ & $\begin{array}{l}1 \quad \text { Maynila sa mga Kuko ng Liwanag (Lino } \\
\text { Brocka, 1975) }\end{array}$ \\
\hline $\begin{array}{l}\text { Ganito Kami Noon... Paano Kayo Ngayon? } \\
\text { (Eddie Romero, 1976) }\end{array}$ & Himala (Ishmael Bernal, 1982) \\
\hline Anak Dalita (Lamberto Avellana, 1956) & Kisapmata (Mike de Leon, 1981) \\
\hline Manila By Night (Ishmael Bernal, 1980) & Manila By Night (Ishmael Bernal, 1980) \\
\hline Kisapmata (Mike de Leon, 1981) & Oro Plata Mata (Peque Gallaga, 1982) \\
\hline Insiang (Lino Brocka, 1976) & $6 \quad$ Biyaya ng Lupa (Silos, 1959) \\
\hline Biyaya ng Lupa (Manuel Silos, 1959) & $7 \quad$ Insiang (Lino Brocka, 1976) \\
\hline Himala (Ishmael Bernal, 1982) & Ganito Kami Noon... Paano Kayo Ngayon? \\
\hline Nunal sa Tubig (Ishmael Bernal, 1976) & Batch '81 (Mike de Leon, 1982) \\
\hline 10 Oro Plata Mata (Peque Gallaga, 1982) & $\begin{array}{l}10 \text { Tinimbang Ka Ngunit Kulang (Lino Brocka, } \\
\text { 1974) }\end{array}$ \\
\hline 11 Jaguar (Lino Brocka, 1979) & 11 Mababangong Bangungot (Tahimik, 1977) \\
\hline 12 Moral (Marilou Diaz-Abaya, 1982) & 12 Itim (Mike de Leon, 1976) \\
\hline $\begin{array}{l}13 \text { Tinimbang Ka Ngunit Kulang (Lino Brocka, } \\
\text { 1974) }\end{array}$ & Batang West Side (Lav Diaz, 2001) \\
\hline 14 Itim (Mike de Leon, 1976) & $\begin{array}{l}14 \text { Ebolusyon ng Isang Pamilyang Pilipino (Lav } \\
\text { Diaz, 2004) }\end{array}$ \\
\hline 15 Noli Me Tangere (Gerardo de Leon, 1961) & 15 Nunal sa Tubig (Ishmael Bernal, 1976) \\
\hline 16 Salome (Laurice Guillen, 1981) & 16 Burlesk Queen (Celso Ad. Castillo, 1977) \\
\hline 17 Hinugot sa Langit (Ishmael Bernal, 1985) & 17 Anak Dalita (Lamberto Avellana, 1956) \\
\hline 18 II Filibusterismo (Gerardo de Leon, 1962) & 18 Orapronobis (Lino Brocka, 1989) \\
\hline 19-20 Badjao (Lamberto Avellana, 1957) & 19 Kakabakaba Ka Ba? (Mike de Leon, 1980) \\
\hline 19-20 Burlesk Queen (Celso Ad. Castillo, 1977) & 20 Karnal (Marilou Diaz-Abaya, 1984) \\
\hline
\end{tabular}




\begin{tabular}{|c|c|c|c|}
\hline $21-22$ & $\begin{array}{l}\text { Daigdig ng mga Api (Gerardo de Leon, } \\
\text { 1965) }\end{array}$ & 21 & $\begin{array}{l}\text { Tatlong Taong Walang Diyos (Mario O'Hara, } \\
\text { 1976) }\end{array}$ \\
\hline $21-22$ & $\begin{array}{l}\text { Sawa sa Lumang Simboryo (Gerardo de } \\
\text { Leon, 1952) }\end{array}$ & 22 & Moral (Marilou Diaz-Abaya, 1982) \\
\hline 23 & $\begin{array}{l}\text { Hanggang sa Dulo ng Daigdig (Gerardo } \\
\text { de Len, 1958) }\end{array}$ & 23 & Genghis Khan (Manuel Conde, 1950) \\
\hline 24 & $\begin{array}{l}\text { Minsa'y Isang Gamugamo (Lupita } \\
\text { Concio-Kashiwahara, 1976) }\end{array}$ & 24 & Scorpio Nights (Peque Gallaga, 1985) \\
\hline $25-27$ & Batch '81 (Mike de Leon, 1982) & 25 & Bayaning Third World (Mike de Leon, 1999) \\
\hline $25-27$ & Sakada (Behn Cervantes, 1976) & 26 & Sister Stella L. (Mike de Leon, 1984) \\
\hline $25-27$ & Sisa (Gerardo de Leon, 1951) & 27 & Magnifico (Maryo J. delos Reyes, 2003) \\
\hline $28-29$ & $\begin{array}{l}\text { Miguelito: Ang Batang Rebelde (Lino } \\
\text { Brocka, 1985) }\end{array}$ & 28 & $\begin{array}{l}\text { Ang Pagdadalaga ni Maximo Oliveros } \\
\text { (Auraeus Solito, 2005) }\end{array}$ \\
\hline $28-29$ & $\begin{array}{l}\text { The Moises Padilla Story (Gerardo de } \\
\text { Leon, 1961) }\end{array}$ & 29 & Kinatay (Brillante Mendoza, 2009) \\
\hline 30 & Sister Stella L. (Mike de Leon, 1984) & 30 & Tuhog (Jeffrey Jeturian, 2000) \\
\hline $31-32$ & Genghis Khan (Manuel Conde, 1950) & 31 & Kubrador (Jeffrey Jeturian, 2006) \\
\hline $31-32$ & $\begin{array}{l}\text { Tatlong Taong Walang Diyos (Mario } \\
\text { O'Hara, 1976) }\end{array}$ & 32 & Bagets (Maryo J. delos Reyes, 1984) \\
\hline 33-34 & Bona (Lino Brocka, 1980) & 33 & Babae sa Breakwater (Mario O'Hara, 2003) \\
\hline 33-34 & Sanda Wong (Gerardo de Leon, 1955) & 34 & $\begin{array}{l}\text { Pagputi ng Uwak, Pag-Itim ng Tagak (Celso } \\
\text { Ad. Castillo, 1978) }\end{array}$ \\
\hline $35-36$ & Brutal (Marilou Diaz-Abaya, 1980) & 35 & Badjao (Lamberto Avellana, 1957) \\
\hline $35-36$ & Virgin Forest (Peque Gallaga, 1985) & 36 & $\begin{array}{l}\text { Death in the Land of Encantos (Lav Diaz, } \\
\text { 2007) }\end{array}$ \\
\hline 37 & $\begin{array}{l}\text { Kundiman ng Lahi (Lamberto Avellana, } \\
\text { 1959) }\end{array}$ & 37 & Aguila (Eddie Romero, 1980) \\
\hline $38-39$ & Kakabakaba Ka Ba? (Mike de Leon, 1980) & 38 & $\begin{array}{l}\text { Bayan Ko: Kapit sa Patalim (Lino Brocka, } \\
\text { 1985) }\end{array}$ \\
\hline $38-39$ & Scorpio Nights (Peque Gallaga, 1985) & 39 & Oliver (Nick Deocampo, 1983) \\
\hline $40-42$ & Boatman (Tikoy Aguiluz, 1984) & 40 & Ang Tatay Kong Nanay (Lino Brocka, 1978) \\
\hline
\end{tabular}




\begin{tabular}{|c|c|c|c|}
\hline $40-42$ & $\begin{array}{l}\text { Ligaw na Bulaklak (Ishmael Bernal, } \\
\text { 1976) }\end{array}$ & 41 & $\begin{array}{l}\text { Kung Mangarap Ka't Magising (Mike de } \\
\text { Leon, 1977) }\end{array}$ \\
\hline $40-42$ & Relasyon (Ishmael Bernal, 1982) & 42 & Salawahan (Ishmael Bernal, 1979) \\
\hline $43-44$ & $\begin{array}{l}\text { Bayan Ko: Kapit sa Patalim (Lino Brocka, } \\
\text { 1985) }\end{array}$ & 43 & Relasyon (Ishmael Bernal, 1982) \\
\hline $43-44$ & Ifugao (Gerardo de Leon, 1954) & 44 & Hinugot sa Langit (Ishmael Bernal, 1985) \\
\hline $45-47$ & 48 Oras (Gerardo de Leon, 1950) & 45 & $\begin{array}{l}\text { The Moises Padilla Story (Gerardo de Leon, } \\
\text { 1961) }\end{array}$ \\
\hline $45-47$ & Broken Marriage (Ishmael Bernal, 1983) & 46 & Bona (Lino Brocka, 1980) \\
\hline $45-47$ & Ikaw Ay Akin (Ishmael Bernal, 1978) & 47 & El Filibusterismo (Gerardo de Leon, 1962) \\
\hline $48-49$ & $\begin{array}{l}\text { Geron Busabos: Ang Batang Quiapo } \\
\text { (Cesar Gallardo, 1964) }\end{array}$ & 48 & $\begin{array}{l}\text { A Portrait Of The Artist As Filipino (Lamberto } \\
\text { Avellana, 1965) }\end{array}$ \\
\hline $48-49$ & Malvarosa (Gregorio Fernandez, 1958) & 49 & Malvarosa (Gregorio Fernandez, 1958) \\
\hline $50-51$ & $\begin{array}{l}\text { High School Circa'65 (Maryo J. Delos } \\
\text { Reyes, 1979) }\end{array}$ & 50 & $\begin{array}{l}\text { Ang Damgo ni Eleuteria (Remton Siega } \\
\text { Zuasola, 2010) }\end{array}$ \\
\hline $50-51$ & $\begin{array}{l}\text { Higit sa Lahat (Gregorio Fernandez, } \\
\text { 1955) }\end{array}$ & 51 & Thy Womb (Brillante Mendoza, 2012) \\
\hline
\end{tabular}

SKILTY C. LABASTILLA is a Research Associate at the Institute of Philippine Culture and a Lecturer at Ateneo de Manila University's Department of Sociology and Anthropology. He is a member and former president of the Young Critics Circle Film Desk. (corresponding author: slabastilla@gmail.com ). 
